\author{
IngA Dudek, AgNiEsZKa KWIATEK
}

\author{
Zakład Wirusologii Molekularnej \\ Instytut Mikrobiologii \\ Wydział Biologii \\ Uniwersytet Warszawski \\ Miecznikowa 1, 02-096 Warszawa \\ E-mail:akwiat@biol.uw.edu.pl \\ inga.dudek.id@gmail.com
}

\title{
CHARAKTERYSTYKA BETACORONAVIRUSÓW ORAZ WARIANTÓW SARS-CoV-2
}

\section{KLASYFIKACJA CORONAVIRIDAE}

Do rodziny Coronaviridae, należącej do rzędu Nidovirales i podrzędu Coronidovirinae, zaliczane sa dwie podrodziny: Orthocoronavirinae i Letovirinae. Wirusy infekujace człowieka zaklasyfikowane zostały do dwóch rodzajów podrodziny Orthocoronavirinae: Alfacoronavirus i Betacoronavirus. Koronawirus 229E (HCoV-229E) i HCoV-NL63 reprezentuja rodzaj Alfacoronavirus, natomiast SARS-CoV, MERS-CoV, SARS-CoV-2, HCoV-HKU-1 i HCoV-OC43 - Betacoronavirus.

SARS-CoV, MERS-CoV i SARS-CoV-2 sa wysoce patogennymi odzwierzęcymi wirusami, podczas gdy inne koronawirusy zakażające ludzi powoduja głównie infekcje łagodne, bezobjawowe. SARS-CoV pojawił się w Guangdong w Chinach w 2002 r., MERS-CoV na Półwyspie Arabskim w 2012 r., a SARS-CoV-2 został odkryty w grudniu 2019 r. w Wuhan w Chinach. SARS-CoV-2, czynnik etiologiczny choroby koronawirusowej 2019 (COVID-19), pojawił się w Chinach i rozprzestrzenił sie globalnie, powodujac pandemię $z$ ponad 241411380 potwierdzonych przypadków, w tym 4912112 zgonów na dzień 20 października 2021.

\section{STRUKTURA WIRIONU ORAZ GENOM BETACORONAVIRUS}

Wirion ma kształt kulisty lub owalny, o średnicy od 60 do $140 \mathrm{~nm}$. Helikalny nukle- okapsyd, składajacy się $\mathrm{z}$ wirusowego RNA i białek nukleokapsydu (N), otoczony jest osłonka lipidowa, w której zakotwiczone sa białka kolca (ang. spike, S), białka błonowe (M) i białka otoczki (E).

Genom wirusa to jednoniciowy RNA o polarności dodatniej, o długości $\sim 30 \mathrm{kpz}$, zakończony strukturą cap na końcu 5' i ogonem poliA na końcu 3'. Sekwencja kodujaca białka wirusowe jest otoczona przez $5^{\prime}$ i 3' regiony nieulegajace translacji (UTR).

5' proksymalna część genomu, obejmująca ponad dwie trzecie genomu, zawiera ORF1a i ORF1b kodujace poliproteiny orf1ab, podczas gdy 3' zawiera geny białek strukturalnych, w tym białka S, E, M i N (SRINIVASAN i współaut. 2020).

\section{BIAŁKA WIRUSOWE}

$\mathrm{Na}$ zewnatrz lipidowej osłonki wirusowej wystaje 1200 aminokwasowe białko kolca zaangażowane $\mathrm{w}$ adsorpcję wirusa i jego wniknięcie do komórek gospodarza. Białko to wiaże się do receptora ACE2 (ang. angiotensin-converting enzyme 2) na powierzchni infekowanych komórek. W czasie infekcji glikoproteina S jest aktywowana poprzez cięcie przez komórkowe proteazy na 2 podjednostki: S1 i S2. Podjednostka S1 rozpoznaje receptor ACE2 przez konserwowana domenę RBD (ang. receptor binding domain) zawierajaca motyw RBM (ang. receptor binding motif). Zakotwiczona w osłonce lipidowej S2 
podjednostka S2 odpowiada za fuzję osłonki lipidowej wirusa i błony komórkowej infekowanych komórek (HATMAL i współaut. 2020, KE i współaut. 2020, LAN i współaut. 2020, WALLS i współaut. 2020).

W porównaniu $z$ SARS-CoV i MERS-CoV, białko kolca posiada dodatkowe miejsce rozpoznawane i cięte przez komórkowe furyny, co może wpływać na większa patogenność SARS-CoV-2.

Białko $\mathrm{S}$ będace głównym antygenem wirusowym jest $\mathrm{N}$-glikozylowane. Modyfikacja ta odgrywa istotna rolę $\mathrm{w}$ uzyskaniu prawidłowej struktury białka oraz $\mathrm{w}$ unikaniu odpowiedzi immunologicznej przez wirusa, modulując rozpoznawanie go przez przeciwciała (WATANABE i współaut. 2020).

Białko E (ang. envelope) i białko M (ang. membrane) sa kolejnymi białkami zakotwiczonymi w osłonce lipidowej wirusa. Białko E Betacoronavirus jest zaangażowane w cykl replikacyjny uczestniczac $\mathrm{w}$ składaniu czastek wirusowych, wypaczkowywaniu potomnych czastek wirusowych, powstawaniu osłonki lipidowej i patogenezę. Brak lub inaktywacja białka E skutkuje atenuacja wirusa. Dodatkowo białko to działa jak wiroporyna permabilizująca błonę komórkowa zainfekowanych komórek, ułatwiając uwolnienie potomnych cząstek wirusowych. Białko $\mathrm{E}$ oddziałuje $\mathrm{z}$ innymi białkami wirusowymi, białkiem M, N i S (SCHOEMAN i FIELDING 2019).

Białko $M$ jest najliczniejszym strukturalnym białkiem wirusowym zakotwiczonym $\mathrm{w}$ osłonce lipidowej. W wyniku interakcji $z$ innymi białkami wirusowymi, białko to jest zaangażowane $\mathrm{w}$ replikacje i składanie czastek wirusowych. Oddziałując $z$ białkiem $\mathrm{N}$, białko $\mathrm{M}$ stabilizuje nukleokapsyd i wewnętrzny rdzeń wirionów oraz uczestniczy w składaniu cząstek wirusowych (Lu i współaut. 2021). Natomiast jego oddziaływanie $z$ białkiem S przyczynia się do wbudowania białka S do nowych wirionów. Ponadto, białko M SARS-CoV-2, wpływając na szlak sygnałowy RIG-I/MDA-5, hamuje wytwarzanie interferonu typu I i III (ZHENG i współaut. 2020).

Białko N buduje nukleokapsyd chroniacy genom wirusa. Poza tworzeniem nukleokapsydu, białko $\mathrm{N}$ jest zaangażowane $\mathrm{w}$ regulację syntezy wirusowego RNA w replikacji/ transkrypcji, składaniu wirusa i paczkowaniu, co prowadzi do całkowitego uformowania wirionu (TANG i współaut. 2005, ZENG i współaut. 2020). Białko $\mathrm{N}$ bierze również udział $\mathrm{w}$ interakcjach gospodarz-patogen poprzez wpływ na reorganizację aktyny, progresję cyklu komórkowego gospodarza i apoptoze. Podobnie jak w przypadku SARS$-\mathrm{CoV}$, białko $\mathrm{N}$ wirusa SARS-CoV-2 jest wy- soce immunogennym antygenem wirusowym, zdolnym do indukowania ochronnych odpowiedzi immunologicznych wobec SARS$-\mathrm{CoV}-2$.

Ponadto, w genomie wirusa zapisana jest informacja o wielu białkach niestrukturalnych zaangażowanych $\mathrm{w}$ replikację genomu wirusa, namnażanie się wirusów i oddziaływanie $z$ komórkami gospodarza (HATMAL i współaut. 2020).

\section{CYKL REPLIKACYJNY BETACORONAVIRUS}

Aby wniknąć do komórek gospodarza, wirus wiąże się najpierw $z$ powierzchnia komórki, a przyłączenie wirusa odbywa się poprzez interakcje pomiędzy jednostką powierzchniową $\mathrm{S} 1$ białka $\mathrm{S}$ i jego komórkowym receptorem. Interakcja ta jest głównym czynnikiem determinującym infekcję komórki gospodarza i kontrolujacym tropizm tkankowy wirusa. W dojrzałym wirusie białko $\mathrm{S}$ występuje $\mathrm{w}$ postaci trimeru, $\mathrm{z}$ trzema podjednostkami S1 wiążącymi receptor, osadzonymi na podjednostce S2 (SHANG i współaut. 2020).

Przyłączenie się podjednostki S1 do receptora komórkowego stymuluje endocytozę wirusa do komórki gospodarza lub też dochodzi do fuzji osłonki wirusowej $z$ błona komórkowa komórek gospodarza (BENTON i współaut. 2020, CHAMBERS i współaut. 2020). Następnie, $z$ udziałem podjednostki S2, dochodzi do fuzji lipidowej osłonki wirusa $z$ błona endosomalna, co powoduje uwolnienie nukleokapsydu do cytozolu komórki, gdzie zachodza dalsze etapy cyklu replikacyjnego. Jak wspomniano wcześniej, warunkiem koniecznym do zajścia fuzji jest proteolityczna aktywacja białka kolca przez komórkowe proteazy: TMPRSS2 i lizosomalna katepsynę (HoFFMANN i współaut. 2020). Dodatkowo, białko kolca SARS-CoV-2 jest aktywowane poprzez cięcie furyna (COUTARD i współaut. 2020).

W następnych etapach cyklu replikacyjnego zachodza kolejno: (1) synteza i proteolityczne cięcie poliproteiny do 16 białek niestrukturalnych, które tworza kompleks replikazy/transkryptazy katalizujacy replikację i transkrypcję genomu wirusowego; (2) synteza genomowego RNA i subgenomowych mRNA; (3) translacja białek strukturalnych kodowanych $z$ subgenomowych mRNA; (4) składanie i uwolnienie potomnych cząstek wirusowych na drodze egzocytozy.

\section{PATOGENEZA SARS-CoV-2}

Jak wspomniano powyżej, SARS-CoV-2 wiąże się z ACE2 (konwertaza angiotensyny 
2), enzymu przekształcającego angiotensynę I do angiotensyny (1-9), zaangażowanych w regulację skurczu naczyń krwionośnych i ciśnienia krwi. ACE2 ulega ekspresji w komórkach błony śluzowej nosa, oskrzeli, płuc, serca, przełyku, nerek, żołąka, pęcherza moczowego i jelita krętego, a zatem wszystkie te narzady ludzkie sa podatne na zakażenie SARS-CoV-2 (LI i współaut. 2020).

SARS-CoV-2 jest przenoszony głównie droga kropelkowa, kontaktowa i potencjalnie droga fekalno-oralna (HARRISON i współaut. 2020). Przyjmuje się, że pierwotna replikacja wirusa zachodzi w nabłonku śluzówki górnych dróg oddechowych, a dalsze namnażanie w dolnych drogach oddechowych. Niektóre infekcje zostaja opanowane na tym etapie i pozostaja bezobjawowe, inne natomiast moga powodować łagodne, umiarkowane lub ciężkie objawy, $z$ zapaleniem płuc lub uszkodzeniem innych narzadów włącznie.

Główne zmiany patologiczne w drogach oddechowych u pacjentów zakażonych SARS-CoV-2 obejmuja rozlane uszkodzenie pęcherzyków płucnych $z$ różnym stopniem nasilenia ostrych cech wysiękowych. W płucach obserwuje się również śródmiąższowe jednojądrowe nacieki zapalne, w których dominuja limfocyty. U pacjentów moga również wysteppować objawy nieoddechowe, takie jak ostre uszkodzenie watroby i serca, niewydolność nerek czy biegunka, sugerujace zajęcie wielu narząów (HUANG i współaut. 2020, PARK 2020).

U pacjentów $z$ COVID-19 może dochodzić także do zaburzeń w układzie odpornościowym. Zmiany immunologiczne obejmuja zmiany w liczbie i funkcjonowaniu komórek układu odpornościowego. Infekcja może powodować limfopenię (cytotoksyczne limfocyty
T), eozynopenię, wzrost liczby reaktywnych komórek ostrej fazy lub zaburzona odpowiedź komórek T.

Wiele danych wskazuje na to, że patogeneza SARS-CoV-2 może być również związana $z$ zespołem burzy cytokinowej, czyli ogólnoustrojową odpowiedzia zapalna na antygeny patogenu. W zakażeniu wirusem SARS-CoV-2 stwierdzono zwiększone stężenie osoczowych mediatorów prozapalnych, w tym: IL1- $\beta$, IL1RA, IL7, IL8, IL9, IL10, podstawowego FGF2, GCSF, GMCSF, IFNy, IP10, MCP1, MIP1a, MIP1 $\beta$, PDGFB, TNFa i VEGFA (KIRTIPAL i współaut. 2020, XU i współaut. 2020, BAKHIET i TAURIN 2021). Burza cytokinowa jest głównym czynnikiem rozwoju rozsianego wykrzepiania wewnątrznaczyniowego i zespołu ostrej niewydolności oddechowej (ARDS). Ten ostatni, w wyniku burzy cytokinowej, wywołuje niszczacy atak na organizm, powodując niewydolność wielu narząów, a następnie prowadzi do śmierci.

\section{WARIANTY WIRUSA SARS-CoV-2}

W trakcie rozwoju pandemii pojawiły się różne warianty wirusa SARS-CoV-2, które dotycza głównie zmian w domenie RBD białka kolca (Tabela 1) (BIAN i współaut. 2021, LAURING i HODCROFT 2021, SINGH i współaut. 2021). Wszystkie mutacje domeny wiążącej komórkowy receptor ACE2 (RBD) prowadza do zwiększonej transmisyjności, np. mutacja N501Y zwiększa efektywność wiąania RBD-ACE2, a mutacja L452R dodatkowo obniża specyficzność niektórych przeciwciał.

Światowa Organizacja Zdrowia (WHO) wyróżniła ponadto warianty SARS-Cov-2, jako warianty pozostajace pod obserwacją (Tabela 2).

Tabela 1. Warianty SARS-Cov-2 wyróżnione przez WHO jako warianty ryzyka (VOC, „Variants of concern").

Pogrubiona czcionka zaznaczono mutacje w rejonie RBM (receptor-binding motif); *mutacja E484K została niedawno wykryta również w wariancie a.

\begin{tabular}{|c|c|c|c|c|}
\hline Nazewnictwo WHO & Rodowód & Data i miejsce wykrycia & $\begin{array}{l}\text { Nabyte mutacje } \\
\text { (ilość) }\end{array}$ & Mutacje białka S, domena RBD \\
\hline Alpha & B.1.1.7 & $\begin{array}{l}\text { Wrzesień } 2020 \\
\text { Wielka Brytania }\end{array}$ & 17 & N501Y, E484K* \\
\hline Beta & B. 1.351 & $\begin{array}{l}\text { Maj } 2020 \\
\text { Południowa Afryka }\end{array}$ & 23 & $\begin{array}{l}\mathrm{K} 417 \mathrm{~N}, \mathbf{E 4 8 4 K}, \\
\mathbf{N 5 0 1 Y}\end{array}$ \\
\hline Gamma & P. 1 & $\begin{array}{l}\text { Listopad } 2020 \\
\text { Brazylia }\end{array}$ & 21 & K417T, E484K, N501Y \\
\hline Delta & B.1.617.2 & $\begin{array}{l}\text { Październik } 2020 \\
\text { Indie }\end{array}$ & 17 & $\begin{array}{l}\text { L452R, T478K, } \\
\text { K417N - „Delta plus” }\end{array}$ \\
\hline
\end{tabular}


Tabela 2. Warianty SARS-CoV-2 wyróżnione przez WHO jako warianty pozostające pod obserwacją (VOI, „Variants of interest”).

\begin{tabular}{llll}
\hline Nazewnictwo WHO & Rodowód & Data i miejsce wykrycia \\
\hline$\varepsilon$ & Epsilion & B.1.427/ B.1.429 & $\begin{array}{l}\text { Marzec 2020 } \\
\text { Stany Zjednoczone }\end{array}$ \\
\hline$\zeta$ & Zeta & P.2 & $\begin{array}{l}\text { Kwiecień 2020 } \\
\text { Brazylia }\end{array}$ \\
\hline$\eta$ & Eta & B.1.525 & $\begin{array}{l}\text { Grudzień 2020 } \\
\text { Różne lokacje }\end{array}$ \\
\hline$\theta$ & Theta & P.3 & $\begin{array}{l}\text { Styczeń 2021 } \\
\text { Filipiny }\end{array}$ \\
\hline 1 & Iota & B.1.526 & $\begin{array}{l}\text { Listopad 2020 } \\
\text { Stany Zjednoczone }\end{array}$ \\
\hline K & Kappa & B.1.617.1 & $\begin{array}{l}\text { Październik 2020 } \\
\text { Indie }\end{array}$ \\
\hline$\lambda$ & Lambda & C.37 & $\begin{array}{l}\text { Sierpień 2020 } \\
\text { Peru }\end{array}$ \\
\hline
\end{tabular}

Obecnie dostępnych jest kilka typów szczepionek chroniacych przed COVID-19. Pierwszy program masowych szczepień rozpoczał się na początku grudnia 2020 r., a liczba podanych dawek szczepionek jest codziennie aktualizowana. Dotychczas podano co najmniej 13 różnych szczepionek skonstruowanych $\mathrm{w}$ oparciu o różne platformy np.: mRNA białka kolca [np. szczepionka Pfizer/BioNtech Comirnaty, Moderna COVID-19 vaccine (mRNA 1273)], niereplikujacy się wektor wirusowy (AstraZeneca/AZD1222, Janssen/Ad26.COV 2.S) (BAKHIET i TAURIN 2021, XIA 2021).

Szczepionka Pfizer/BioNtech Comirnaty została wpisana na listę WHO do użytku doraźnego 31 grudnia 2020 r. Szczepionki SII/Covishield i AstraZeneca/AZD1222 otrzymały pozwolenia na dopuszczenie do obrotu 16 lutego 2021 r. Szczepionka Janssen/Ad26.COV 2.S opracowana przez firmę Johnson \& Johnson została wpisana na listę EUL (ang. Emergency Use Listing) 12 marca 2021 r., szczepionka Moderna COVID-19 (mRNA 1273) 30 kwietnia 2021 r., szczepionka Sinopharm COVID-19 7 maja 2021 r., a szczepionka Sinovac-CoronaVac 1 czerwca 2021 r.

W Europie najczęściej stosowane sa: AstraZeneca/AZD1222 (Vaxzevira), Janssen/ Ad26.COV 2.S, Moderna COVID-19 vaccine (mRNA 1273) i Pfizer/BioNtech Comirnaty).

Jak wspomniano, przeprowadzone analizy in vitro sugeruja obniżona wrażliwość wariantów ryzyka na działanie surowic. Te wyniki, choć niepokojace, nie powinny być rozumiane jako jednoznaczne $z$ obniżona efektywnością szczepionek. Badania przeprowadzone w 2021 r. potwierdzaja, że szczepionki będace w obiegu wciąż zapewniaja ochronę przed ciężkim przebiegiem choroby i zgonem na skutek infekcji SARS-CoV-2.

Najczęściej stosowane w Europie szczepionki [AstraZeneca/AZD1222 (Vaxzevira), Janssen/Ad26.COV 2.S, Moderna COVID-19 vaccine (mRNA 1273), Pfizer/BioNtech Comirnaty] wcią̇ zapewniaja wysoki poziom ochrony przed infekcją wariantem a, $Z$ efektywnościa wahajacca się w granicach 75-86\% (BIAN i współaut. 2021, KUSTIN i współaut. 2021).

Wariant pochodzaccy $z$ Indii, charakteryzujący się podwojona infekcyjnością w stosunku do wariantu a, jest intensywnie badany pod katem odporności na szczepienia. Dotychczasowe dane wskazuja, że pomimo spadku o $10 \%$ na efektywności w zapobieganiu rozwinięcia symptomów choroby i nawet $20 \% \mathrm{w}$ zapobieganiu samej infekcji, dla tego wariantu wirusa szczepionka Pfizer/BioNtech Comirnaty nadal wykazuje skuteczność. Analogiczne dane dotyczace ryzyka zachorowania uzyskano dla preparatu AstraZeneca/ AZD1222 (Vaxzevira). Dane dotyczace szczepionki Moderna COVID-19 vaccine (mRNA 1273) wskazuja jedynie na jej skuteczność w zapobieganiu ostrego stanu chorobowego, brak jest danych dotyczacych jej skuteczności w zapobieganiu infekcji.

Dane zebrane dla wariantu $\beta$ sa podobne. Szczepionka Pfizer/BioNtech Comirnaty wywołuje wysoki poziom ochrony $(75 \%)$, Janssen wykazuje efektywność w granicach $64 \%$, a Novavax ok. 60\%. W lutym 2021 r. koncern Moderna rozpoczal badania nad nowa szczepionka skierowana na wariant $\beta$, jako że dostepny preparat nie wywoływał wystarczajacej odpowiedzi immunologicznej, by przeciwdziałać infekcji tym wariantem. Efektywność szczepionki AstraZeneca/ AZD1222 (Vaxzevira) w zapobieganiu infekcji 
okazała się niewystarczająca, skutkiem czego w RPA wycofano preparat, zastepując go produktem Johnson\&Johnson. Bardzo mało jest dostępnych badań na temat efektu wariantu $\delta$, jednak dostepne wyniki sugeruja niższa neutralizację wirusa przez szczepionki Moderna COVID-19 vaccine (mRNA 1273) i Pfizer/BioNtech Comirnaty (GARCIA-BELTRAN i współaut. 2021, GUPTA 2021).

$$
\text { Streszczenie }
$$

SARS-CoV-2, czynnik etiologiczny choroby koronawirusowej 2019 (COVID-19), pojawił się w Chinach w 2019 i rozprzestrzenił się globalnie, powodując pandemię. W niniejszej pracy przedstawiamy stan wiedzy o SARS-CoV-2 uwzględniając budowę i rolę białek: kolca S, E, M i N, a także cykl replikacyjny tego wirusa. Szczególnie istotne jest białko kolca, ponieważ w trakcie rozwoju pandemii pojawiły się różne warianty wirusa SARS-CoV-2, które dotycza głównie zmian w tym białku, a charakteryzuja się zwiększoną infekcyjnością.

\section{LITERATURA}

BAKHIET M., TAURIN S., 2021. SARS-CoV-2: Targeted managements and vaccine development. Cytokine Growth Factor Rev. 58, 16-29.

Benton D. J., Wrobel A. G., Xu P., Roustan C., Martin S. R., Rosenthal P. B., Skehel J. J., GAMBLIN S. J., 2020. Receptor binding and priming of the spike protein of SARS-CoV-2 for membrane fusion. Nature 588, 327-330.

Bian L., GaO F., ZHANG J., HE Q., MAO Q., XU M., LIANG Z., 2021. Effects of SARS-CoV-2 variants on vaccine efficacy and response strategies. Expert Rev. Vac. 20, 365-373.

Chambers J. P., Yu J., Valdes J. J., ARulanandam B. P., 2020. SARS-CoV-2, early entry events. J. Pathog. 2020, doi: 10.1155/2020/9238696.

Coutard B., Valle C., De lamballerie X., CANARD B., SEIDAH N. G., DECROlY E., 2020. The spike glycoprotein of the new coronavirus 2019-nCoV contains a furin-like cleavage site absent in CoV of the same clade. Antiviral Research 176, doi: 10.1016/j.antiviral.2020.104742.

Garcia-Beltran W. F., lam E. C., Denis K. S., Nitido A. D., GaRcia Z. H., Hauser B. M., FELDMAN J., PAVLOVIC M. N., GREGORY D. J., POZNANSKY M. C., Sigal A., SChMidT A. G., IAFRATE A. J., NARANBHAI V., BALAZS A. B., 2021. Circulating SARS-CoV-2 variants escape neutralization by vaccine-induced humoral immunity. medRxiv: 2021.2002.2014.21251704.

GUPTA R. K., 2021. Will SARS-CoV-2 variants of concern affect the promise of vaccines? Nat. Rev. Immunol. 21, 340-341.

HARRISON A. G., LiN T., WANG P., 2020. Mechanisms of SARS-CoV-2 transmission and pathogenesis. Trends Immunol. 41, 1100-1115.

Hatmal M. M., Alshaer W., Al-Hatamleh M. A. I., Hatmal M., Smadi O., Taha M. O., OWeIDA A. J., BOER J. C., MOHAMUd R., PLEBANSKI M., 2020. Comprehensive structural and molecular comparison of spike proteins of SARS-CoV-2, SARS-CoV and MERS-CoV, and their interactions with ACE2. Cells 9, doi: 10.3390/ cells9122638.

Hoffmann M., Kleine-Weber H., Schroeder S., KrÜGER N., HERRler T., ERICHSEN S., SCHIERGENS T. S., HERRLER G., WU N.-H., NITSCHE A., MÜller M. A., DROSTEN C., PÖHLMANN
S., 2020. SARS-CoV-2 cell entry depends on ACE2 and TMPRSS2 and is blocked by a clinically proven protease inhibitor. Cell 181, 271-280.

Huang C., Wang Y., Li X., Ren L., Zhao J., Hu Y., ZHANG L., FAN G., XU J., GU X., CHENG Z., YU T., XIA J., WeI Y., WU W., XIE X., YIN W., Li H., LiU M., XiaO Y., GaO H., GuO L., XIE J., WANG G., JiANG R., GaO Z., JiN Q., WANG J., CAO B., 2020. Clinical features of patients infected with 2019 novel coronavirus in Wuhan, China. Lancet 395, 497-506.

Ke Z., OTON J., QU K., CORTESE M., ZILA V., MCKEANE L., NAKANE T., ZivanOV J., NEUfEldT C. J., Cerikan B., Lu J. M., Peukes J., Xiong X., KräUsslich H. G., Scheres S. H. W., BARTENSCHLAGER R., BRIGGS J. A. G., 2020. Structures and distributions of SARS-CoV-2 spike proteins on intact virions. Nature 588, 498-502.

KIRTIPAL N., BHARADWAJ S., KANG S. G., 2020. From SARS to SARS-CoV-2, insights on structure, pathogenicity and immunity aspects of pandemic human coronaviruses. Infect. Genet. Evol. 85, doi: 10.1016/j.meegid.2020.104502.

Kustin T., Harel N., Finkel U., PERChiK S., HARARI S., TAHOR M., CASPI I., LEVY R., LESHCHINSKY M., KEN DROR S., BERGERZON G., Gadban H., Gadban F., Eliassian E., SHimron O. i współaut., 2021. Evidence for increased breakthrough rates of SARS-CoV-2 variants of concern in BNT162b2-mRNA-vaccinated individuals. Nat. Med. 27, 1379-1384.

LaN J., Ge J., Yu J., SHAN S., ZHOU H., FAN S., ZHANG Q., SHI X., WANG Q., ZHANG L., WANG X., 2020. Structure of the SARS-CoV-2 spike receptor-binding domain bound to the ACE2 receptor. Nature 581, 215-220.

LAURING A. S., HODCROFT E. B., 2021. Genetic Variants of SARS-CoV-2 - What do they mean? JAMA 325, 529-531.

LI M.-Y., LI L., ZHANG Y., WANG X.-S., 2020. Expression of the SARS-CoV-2 cell receptor gene ACE2 in a wide variety of human tissues. Infec. Dis. Poverty 9, doi: 10.1186/ s40249-020-00662-X.

LU S., YE Q., SiNGH D., CAO Y., DiEDRICH J. K., Yates J. R. 3RD, Villa E., Cleveland D. W.,CORBETT K. D., 2021. The SARS-CoV-2 nucleocapsid phosphoprotein forms mutually exclusive condensates with RNA and the membrane-associated $M$ protein. Nat Commun 12, doi: $10.1038 / \mathrm{s} 41467-020-20768-y$.

PARK S. E., 2020. Epidemiology, virology, and clinical features of severe acute respiratory syndrome -coronavirus-2 (SARS-CoV-2; Coronavirus Disease-19). Clin. Exp. Pediatr. 63, 119124.

Schoeman D., Fielding B. C., 2019. Coronavirus envelope protein: current knowledge. Virol. J. 16, doi: $10.1186 / \mathrm{s} 12985-019-1182-0$.

Shang J., Wan Y., LuO C., Ye G., Geng Q., AuERBACH A., LI F., 2020. Cell entry mechanisms of SARS-CoV-2. Proc. Natl. Acad. Sci. USA $117,11727-11734$.

Singh J., PANDIT P., MCARTHUR A. G., BANERJEe A., Mossman K., 2021. Evolutionary trajectory of SARS-CoV-2 and emerging variants. Virol. J. $18,166-166$.

SRinivasan S., CUI H., GaO Z., LiU M., LU S., MKANDAWIRE W., NARYKOV O., SUN M., KORKIN D., 2020. Structural genomics of SARS-CoV-2 indicates evolutionary conserved functional regions of viral proteins. Viruses 12, doi: $10.3390 / \mathrm{v} 12040360$. 
TANG T.-K., Wu M. P. J., Chen S.-T., Hou M.-H., HONG M.-H., PAN F.-M., YU H.-M., CHEN J.H., YAO C.-W., WANG A. H. J. 2005 Biochemical and immunological studies of nucleocapsid proteins of severe acute respiratory syndrome and 229E human coronaviruses. Proteomics 5, 925-937.

Walls A. C., PARK Y. J., TORTORICI M. A., WAll A., Mcguire A. T., Veesler D., 2020. Structure, function, and antigenicity of the SARS-CoV-2 spike glycoprotein. Cell 181, 281-292.

Watanabe Y., Allen J. D., WRAPP D., MClellan J. S., CRISPIN M., 2020. Site-specific glycan analysis of the SARS-CoV-2 spike. Science 369, 330-333.

XIA X., 2021. Domains and functions of spike protein in Sars-Cov-2 in the context of vaccine design. Viruses 13, doi: 10.3390/v13010109.

Xu Z., SHI L., WANG Y., ZHANG J., HuANG L., Zhang C., LiU S., ZhaO P., LiU H., Zhu L.,
TAI Y., BAI C., GaO T., SONG J., XIA P., DONG J., ZHAO J., WANG F. S., 2020. Pathological findings of COVID-19 associated with acute respiratory distress syndrome. Lancet Respir. Med. 8, 420-422.

ZENG W., LIU G., MA H., ZHAO D., YANG Y., LIU M., Mohammed A., ZhaO C., Yang Y., XiE J., Ding C., MA X., Weng J., GaO Y., HE H., JIN T., 2020. Biochemical characterization of SARS-CoV-2 nucleocapsid protein. Bioch. Biophys. Res. Comm. 527, 618-623.

ZHENG Y., ZHUANG M. W., HAN L., ZHANG J., NAN M. L., ZhaN P., KANG D., LIU X., GaO C., WANG P. H., 2020. Severe acute respiratory syndrome coronavirus 2 (SARS-CoV-2) membrane $(M)$ protein inhibits type $I$ and III interferon production by targeting RIG-I/MDA-5 signaling. Signal Transduct. Target Ther. 5, doi: $10.1038 / \mathrm{s} 41392-020-00438-7$.

KOSMOS Vol. 70, 3, 383-388, 2021

Inga Dudek, AgnieszKa KWiATeK

Department of Molecular Virology, Institute of Microbiology, Faculty of Biology, University of Warsaw, 1 Miecznikowa Str., 02-096Warszawa,E-mail: akwiat@biol.uw.edu.pl,inga.dudek.id@gmail.com

CHARACTERISTICS OF BETACORONAVIRUSES AND SARS-COV-2 VARIANTS

Summary

SARS-CoV-2, the etiological agent of coronavirus disease 2019 (COVID-19), emerged in China in 2019 and has spread globally, causing a pandemic. In this paper, we report the state of knowledge on SARS-CoV-2 considering the structure and role of spike $(\mathrm{S}), \mathrm{M}, \mathrm{N}$, and $\mathrm{E}$ proteins, as well as the replication cycle of this virus. The spike protein is particularly important because different SARS-CoV-2 variants have emerged during the development of the pandemic. The main changes in virus variants involve changes in this protein and contribute to increased infectivity of SARS-CoV-2.

Key words: SARS-CoV-2, vaccines against SARS-CoV-2, virus variants 